\title{
УДОСКОНАЛЕННЯ ФІЗИЧНОГО ВИХОВАННЯ УЧНІВ МОЛОДШОГО ШКІЛЬНОГО ВІКУ ЗАСОБАМИ ЗАНЯТЬ ПОВІТРЯНОЮ АКРОБАТИКОЮ НА ПОЛОТНАХ
}

\begin{abstract}
Анотація. Загальноосвітні навчальні заклади України пропонують для дітей та батьків цікаві інноваційні програми. Виключенням не стала і школа GlobalKids (м. Львів, Україна) - інноваційний садок та школа, де дітям пропонують не тільки загальноосвітні програми для розвитку учнів, але й додаткові розвиваючі предмети, які дають змогу всесторонньо розвинути особистість дитини. Окрім загальноосвітніх предметів в цій приватній школі дітям запропонували додаткові заняття з фрізичного виховання, а саме, фрутболу, карате, повітряних полотен та ін. Дітям молодшого шкільного віку, яким важко всидіти протягом довгого часу нерухомо - це дає важливу можливість порухатися та набратися додаткової енергії для занять гуманітарними предметами. Тому перед нами була поставлена мета: дослідити методи удосконалення фрізичного виховання учнів молодшого шкільного віку засобами занять повітряною акробатикою на полотнах. Завдяки проведеному дослідженню, ми проаналізували літературу, яка стосуеться питання фізичного виховання учнів молодшого шкільного віку, визначили основні методи їх фрізичного виховання та застосували заняття з повітряної акробатики як засіб удосконалення фрізичного виховання дітей. Інноваційна школа та садок Globalkids дала можливість учням молодшого шкільного віку спробувати власні сили у цьому напрямку та зробити вибір дітям, щодо можливості профресійних занять на повітряних полотнах у Школі повітряної акробатики. Даний експеримент підтверджуе важливість застосування новітніх методів в освіті, адже дає хороші результати для покращення фрізичного стану учнів молодшого шкільного віку та сприяе удосконаленню їхньої фрізичної підготовки.
\end{abstract}

Ключові слова: школа-садок GlobalKids,фрізичне виховання, молодший шкільний вік, методика викладання, повітряна акробатика, повітряні полотна.

\section{Drach Tamara, Cymbalyuk Olena Lviv State University of Physical Culture named after Ivan Bobersky}

\section{IMPROVEMENT OF PRIMARY SCHOOL PUPILS PHYSICAL EDUCATION WITH THE HELP OF AIREAL SILKS CLASSES}

Summary. Secondary schools of Ukraine offer interesting innovative programs for children and parents. The GlobalKids School (Lviv, Ukraine) is no exception - an innovative kindergarten and school, where children are offered not only general education programs for student development, but also additional developmental subjects that allow to fully develop the child's personality. In addition to general education subjects in this private school, children were offered additional classes in physical education, namely, football, karate, aireal silks, etc. Primary school children who find it difficult to sit still for a long time - this gives them an important opportunity to move and gain additional energy for the humanities. Therefore, we had a goal: to explore methods of improving the physical education of primary school students by means of aerial silks. In this regard, the following tasks were set: analyze the literature related to the issue of physical education of primary school students; identify the main methods of physical education of primary school students; use aerial silks classes as a means of improving the physical education of primary school students. Modern methods of physical education of primary school students were researched in the works of Zh.K. Kholodova (2004), I.Ya. Chalenko (2003), O.Ya. Stepanenkova (2006), N.O. Kozlenko (1985). An overview of the main methods of training in aerial acrobatics can be found in the foreign publication Santos Steven «Simply Circus» (2013) and Z.B. Gurevich (1984). However, the question of improving the physical education of primary school students by means of aerial acrobatics on canvases has not yet been raised in modern literature. Due to the research, we analyzed the literature on the issue of physical education of primary school students, identified the main methods of their physical education and used aerial silks trainings as a means of improving the physical education of children. The innovative school and kindergarten GlobalKids gave the opportunity to primary school students to try their forces in this direction and make a choice for children on the possibility of professional training on aireal silks at the School of Aerial Acrobatics. This experiment confirms the importance of using the latest methods in education, because it gives good results to improve the physical condition of primary school students and helps to improve their physical preparation.

Keywords: GlobalKids kindergarten, physical education, primary school age, teaching methods, aerial acrobatics, aerial silks.

$\Pi$ остановка проблеми. Сучасні інноваційні методи освіти включають в себе актуальні напрямки розвитку інтелектуальних та фрізичних здібностей дитини. Все більше шкіл пропонують учням не тільки засвоїти академічні предмети, але й навчитися актуальним мистецьким та спортивним напрямкам. Повітряна акробатика на полотнах - сучасний інноваційний метод удосконалення фрізичного виховання учнів молодшого шкільного віку. Адже дає змогу дитині навчитися виконувати нескладні акробатичні елементи у повітрі, розвиває їхню координацію, баланс, витривалість, гнучкість та пластичність. 
Аналіз останніх досліджень і публікацій. Сучасні методи фізичного виховання учнів молодшого шкільного віку були висвітлені в працях Ж.К. Холодова (2004), І.Я. Чаленко (2003), О.Я. Степаненкової (2006), Н.О. Козленко (1985). Огляд основних методів підготовки у повітряній акробатиці можна знайти в іноземному виданні Santos Steven Simply Circus (2013) та З.Б. Гуревич (1984). Однак питання удосконалення фрізичного виховання учнів молодшого шкільного віку засобами повітряної акробатики на полотнах ще не піднімалося у сучасній літературі.

Виділення невирішених раніше частин загальної проблеми. Питання інновацій у галузі фізичного виховання вже розглядалося у попередніх дослідженнях, та допомогло визначити шляхи удосконалення методів викладання та розвитку дітей молодшого шкільного віку. Тим не менш, питання застосування повітряної акробатики на полотнах як засіб фізичного виховання учнів молодшого шкільного віку у загальноосвітніх школах та актуальність його застосування, це ще малодосліджене, тому вимагає додаткового наукового розгляду.

Формулювання цілей статті. Тому перед нами була поставлена мета: дослідити методи удосконалення фізичного виховання учнів молодшого шкільного віку засобами занять повітряною акробатикою на полотнах.

У зв’язку з цим були поставлені завдання:

- проаналізувати літературу, яка стосуеться питання фізичного виховання учнів молодшого шкільного віку;

- визначити основні методи фізичного виховання учнів молодшого шкільного віку;

- застосувати заняття з повітряної акробатики як засіб удосконалення фрізичного виховання учнів молодшого шкільного віку.

Виклад основного матеріалу дослідження. Фізичне виховання учнів е невід'емною частиною всієї навчально-виховної роботи школи i посідає важливе місце у підготовці учнів до життя та суспільно корисної праці.

Робота 3 фрізичного виховання в школі відрізняеться великим різноманіттям форм, які вимагають від учнів прояву організованості, ініціативи, що сприяе вихованню організаційних навичок, активності, винахідливості. Здійснюване в тісному зв'язку із розумовим, моральним, естетичним вихованням і трудовим навчанням, фізичне виховання сприяе всебічному розвитку школярів [4, с. 22].

Фізичне виховання молодших школярів має свою специфіку, зумовлену їх анатомо-фізіологічними і психологічними особливостями, а також пристосуванням до нових умов. 3 початком навчання значно зростае обсяг розумової праці дітей і відчутно обмежуеться їх фізична активність, можливість перебувати на відкритому повітрі. У зв'язку з цим правильне фізичне виховання в молодшому шкільному віці $\epsilon$ не тільки необхідною умовою всебічного гармонійного розвитку особистості учня, але і дієвим чинником підвищення його розумової працездатності [7, с. 55].

Нова початкова школа GlobalKids - це інноваційний навчальний заклад з авторською програмою навчання та розвитку, у якій дитина гармонійно розвиваеться, навчаючись у атмосфері добра, поваги та, звичайно ж, дисципліни. У цій школі особливе ставлення до дітей, їх вчать не тільки академічним знанням, але й застосовують актуальні моделі успішності. Також їх навчають практичним навичкам і вмінням, які відповідають сучасним викликам глобального світу [3].

На базі школи було встановлене спеціальне обладнання для проведення занять 3 повітряної акробатики, і тим самим створено умови для проведення занять на полотнах. В приміщені висотою 4 м, були підвішені полотна та розміщене спеціальне татамі, котре забезпечуе безпечне проведення занять з повітряних полотен. До занять запросили дітей молодшого шкільного віку( 6-7 років) та почали практикувати з ними акробатичні вправи на полотнах. Для цього 3 ними почав проводити заняття кваліфікований тренер, який допомагає під час виконання елементів.

Заняття $з$ повітряної акробатики в таких навчальних закладах потребуе ретельної організації тренувального простору перед початком занять, адже діти молодшого шкільного віку вимагають до себе активної уваги з боку тренера та класного керівника. Перед заняттям слід підготувати зал, розкласти татамі та розташувати відповідним чином мати (за наявністю) для того, щоб діти мали можливість безпечно виконувати всі необхідні акробатичні елементи. 3 залу слід прибрати всі зайві речі (м'ячі, пірамідки, килимки і т.д.), що може відволікати увагу дітей, адже під час занять вся їхня увага має концентруватися на роботі з тренером та процесу занять на полотнах. Тож, від того, наскільки добре буде організований простір залежить і результативність тренувань.

Повітряні полотна - це різновид повітряної гімнастики, учасники якого виконують трюки на підв'язаних до стелі тканинних полотнах. Цей вид спорту у 90-х роках XX століття популяризував провідний фрранцузький Цирк дю Солей, додавши до нього концепцію повітряних мистецтв як танцювальної форми та театральної виразності, а не суто гімнастичного мистецтва руху $[1$, с. 56].

$\mathrm{y}$ повітряних полотнах $є$ три невіддільні елементи виконання трюків:

- піднімання на висоту використовують під час виконання трюків у повітрі. Існуе три різновиди піднімання - базове, французьке та російське;

- обмотування тканиною - процес обмотування частин тіла гімнаста тканиною, на якій він висить. Цей процес супроводжуеться додатковим гімнастичним елементом - шпагатом, розгойдуванням тощо;

- політ з висоти - техніка падіння, за якої попередньо обмотане полотно розкручуеться та допомагае гімнасту безпечно спуститися на підлогу [2, c. 56].

3 трьох типів трюків політ з висоти $е$ найскладнішим і найнебезпечнішим елементом. Повітряні полотна - мистецтво, яке вимагає високого ступеня міцності, сили, гнучкості, сміливості, витривалості та спроможності багато практикуватися.

Перш ніж, почати роботу на полотнах, необхідно зробити розминку, щоб розігріти м'язи дітей та підготувати тіло учнів до виконання вправ на полотнах. Слід зробити партерну гімнастику, в яку можна включити вправи на розтяжки, підкачку пресу, спини та рук, адже ці м'язи найактивніше залучаються в процесі занять на полот- 


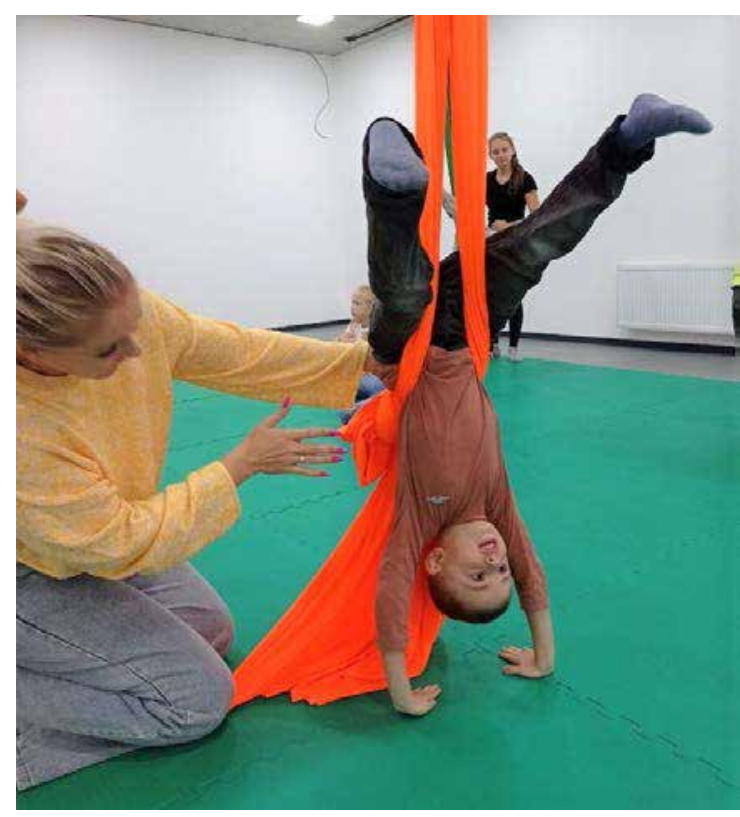

нах. Окрім того, заняття може містити і елементи хореографрічної підготовки. Адже виступи на повітряних полотнах - це не тільки гімнастичні та акробатичні елементи, також це хореографічні зв'язки, вправи у партері, завершенні та статичні позиції, які мають виконуватися граційно та елегантно для кращого сприйняття глядачем виконаних акробатичних елементів (див. фото).

Заняття на полотнах можуть включати в себе вивчення «обмотувань», «висів», «круток» та «зривів». Тож, починати необхідно 3 вивчення найпростіших «обмотувань» ніг та рук, для того, щоб сконцентрувати увагу дитини на важливості цих вправ варто показувати ці елементи спочатку тренеру, а потім вже радити дітям виконувати ці вправи. Діти молодшого шкільного віку можуть працювати на полотнах в парі (коли один виконуе вправу на полотні, інший робить, за завданням тренера, вправи на розтяжку, гнучкість або підкачку м'язів), це допомагає дитині відновити сили після інтенсивної роботи м'язів на полотні, а також задіяти більшу кількість дітей під час занять. Ставати до одного полотна більшою кількістю дітей не рекомендується, адже це затримує час тренувань та робить його малоефективним, адже не дає змогу створити відповідну дисципліну та порядок під час занять.

Перед тренуванням слід добре розігрітися вправами пересувань по колу: це можуть бути кроки по колу, біг, підняття ніг, стрибки, лазіння по підлозі, виконання галопу, або польки, які дозволять, добре розігрітися дитині та привести їі м'язовий корсет у відповідну фрізичну форму перед початком виконання вправ на полотні. 3 дітьми молодшого шкільного віку, варто виконувати нескладні елементи, це можуть бути вправа «свічка", "скорпіон», тримаючись за два полотна, перевороти з зігнутими та рівними ногами, "перекиди». Далі можна переходити до вивчення обмотувань ніг та рук. Вивчення цих елементів може зайняти кілька занять (чотири-п'ять), адже необхідно, щоб кожна дитина добре засвоїла ці прості елементи, які є складовою частиною майже всіх висів та зривів на полотнах. Окрім того, слід враховувати, те що, заняття на полотнах є травмонебезпечним напрямком спорту, тому слід підстраховувати дитину під час виконання вправ, а також слідкувати, щоб діти виконували вправи лише під наглядом тренера.

Після вивчення основних обмотувань, варто пробувати вивчати 3 дітьми шпагати на полотнах, для цього слід обмотати обидві ноги та зробити шпагат у повітрі, робити слід як поперечний, так і поздовжній шпагат. Діти легко виконують ці елементи, адже, хоча вони не $є$ технічно складними, тим не менш, виглядають дуже ефректно.

В інноващійній школі GlobalKids e можливість розмістити фото з занять на власному сайті, де викладачі висвітлюють успішність кожного учня та мають можливість описати успіхи та прогрес кожного виконавця, зробити власні зауваження та надати домашні завдання кожному підопічному, тож, це дає можливість контактувати з батьками, що є дуже важливо для роботи 3 цією віковою категорією дітей.

Після виконання «висів» у шпагат, можна запропонувати дітям навчитися лазити на полотно. Для початку, 3 дітьми варто вивчити звичайний лаз, що дозволить їм у майбутньому виконувати вправи на висоті, що викликає особливе захоплення під час виступів та $є$ важливою передумовою доброго огляду елементу під час його виконання. Після цього з дітьми можна виконувати нескладні виси з замотування одніеї ноги та руки, а також вправи на "вузлику», поперечний шпагат або інші елементи вниз головою, з зачепленням однієї ноги за полотно, важливо навчити дітей залазити наверх, у вузлик, що дозволить пізніше, виконувати їм нескладні зриви.

Після закінчення вправ на полотнах слід перейти до заминки. Для цього слід зійти з татамі або матів та розташуватися з дітьми на середині залу. Для заминки підійдуть вправи por de bras у стилі модерн, або розтягування, в залежності від індивідуальної програми тренера та його планів на подальші елементи. Може підійти, наприклад, plie 3 виконанням body roll або deep body bend, ці вправи добре розтягнуть тіло виконавців та налаштують дитину на більш спокійний ритм для продовження дня. Після заминки слід вивести дітей із залу та передати під нагляд класному керівнику цих учнів, адже дисципліна під час занять на полотнах повітряною акробатикою - $є$ гарантія безпеки дітей, а також, доброго та продуктивного заняття та допоможе у подальшому підготувати дітей до виступів та спрямувати найбільш здібних учнів до професійних навчальних закладів в цьму напрямку.

Важливою складовою ефективності занять є також спілкування 3 батьками, адже кожна дитина вимагає до себе індивідуального підходу. Навчити дітей складним акробатичним елементам на полотнах можливо, коли до дитини знайдений індивідуальний підхід та вона може себе почувати в безпеці, а також буде защікавленою в заняттях. Для цього може стати в нагоді система оцінювання знань підопічних, а також стимулювання їх розвитку завдяки оцінкам, наліпкам, карткам, що буде стимулом для дітей та гарним гарантом їхнього розвитку. Для молодшого шкільного віку така мотивація вкрай важлива, адже вони можуть таким чином відповідати за свої дії перед батьками. 
Висновки 3 даного дослідження i перспективи. Таким чином, завдяки проведеному дослідженню, ми проаналізували літературу, яка стосується питання фізичного виховання учнів молодшого шкільного віку, визначили основні методи їх фрізичного виховання та застосували заняття $з$ повітряної акробатики як засіб удосконалення фрізичного виховання дітей. Інноваційна школа та садок GlobalKids дала можливість учням молодшого шкільного віку спробувати власні сили у џьому напрямку та зробити вибір дітям, щодо можливості професійних занять на повітряних полотнах у Школі повітряної акробатики. Даний експеримент підтверджує важливість застосування новітніх методів в освіті, адже дає хороші результати для покращення фрізичного стану учнів молодшого шкільного віку та сприяе удосконаленню їхньої фрізичної підготовки.

\section{Список літератури:}

1. Santos Steven. Simply Circus. Introduction to Rigging Lyras and Trapeze Bars. Simply Circus, Inc. 2013.

2. Гуревич З.Б. О жанрах советского цирка : учебное пособие для училищ циркового и эстрадного искусства и отделений режиссуры цирка театр, институтов. Москва : Исусство, 1984. 303 с.

3. GlobalKids - інноваційна школа та садок. URL: https:/globalkids.ua/\#section1 (дата звернення: 16.10.2021).

4. Козленко Н.О. Школярам - звичку займатися фізкультурою. Київ, 1985. 120 с.

5. Степаненкова О.Я. Теорія і методика фрізичного виховання та розвитку дитини [Текст] : навч. посіб. для вузів. 2-е вид. Москва : «Академія», 2006. 368 с.

6. Чаленко І.Я. Сучасні уроки фрізкультури в початковій школі. Ростов на Дону, 2003. 255 с.

7. Холодов Ж.К., Кузнецов В.С. Теорія і методика фрізичного виховання і спорту [Текст] : навч. посіб. для студентів вищих навч. закладів. 3-е вид. Москва : «Академія», 2004. 480 с.

\section{References:}

1. Santos Steve (2013) Simply Circus. Introduction to Rigging Lyras and Trapeze Bars. Simply Circus, Inc.

2. Gurevich Z.B. (1984) O zhanrah sovetskogo cyrka [About the genres of the Soviet circus]: a textbook for schools of circus and pop art and departments of circus directing theater, institutes. Moskow: Art, $303 \mathrm{p}$.

3. GlobalKids - innovative school and kindergarten. Available at: https://globalkids.ua/\#section1 (accessed 16 October 2021).

4. Kozlenko N.O. (1985) Shkolyaram - zvychku zaymatysya fizkulturoyu [For the pupils - the habit of physical education]. Kyiv, 120 p.

5. Stepanenkova O.Ya. (2006) Teoriya i metodika phisychnogo vyhovannya ta rozvytku dytyny [Theory and methods of physical education and development of the child]: textbook for universities. 2nd ed. Moscow: "Academy", 368 p.

6. Chalenko I.Ya. (2003) Suchasni uroky phiskultury v pochatkoviy shkoli [Modern physical education lessons in primary school]. Rostov na Donu, $255 \mathrm{p}$.

7. Kholodov Zh.K., Kuznetsov V.S. (2004) Teoriya i metodika physychnogo vyhovannya i sportu [Theory and methods of physical education and sport]: textbook for students of higher education institutions. 3rd edition. Moscow: "Academy", 480 p. 